\title{
Exploring EFL Learners' Self-Efficacy in Academic Writing Based on Process-Genre Approach
}

\author{
Ying Zhang ${ }^{1}$ \\ ${ }^{1}$ English Department, North China Electric Power University, Baoding, Hebei Province, China \\ Correspondence: Ying Zhang, English Department, North China Electric Power University, Baoding, Hebei \\ Province, China
}

Received: March 15, 2018 Accepted: May 15, 2018 Online Published: May 17, 2018

doi: 10.5539/elt.v11n6p115 URL: http://doi.org/10.5539/elt.v11n6p115

\begin{abstract}
This study explores the change of EFL learners' level of self-efficacy in process-genre academic writing instruction. The teaching experiment was conducted for 14 weeks. A total of 59 graduate students participated in the experiment. Before the experiment, the results showed that the general level of EFL graduates' self-efficacy in academic writing was relatively low. After 14 weeks of academic writing instruction conducted by the process-genre approach, participants' self-efficacy improved significantly. In the interview, participants also reported an increasing level of confidence in academic writing. Based on the findings, implications of academic writing instruction to improve students' self-efficacy are discussed in the paper.
\end{abstract}

Keywords: self-efficacy, process-genre approach, EFL learners, academic writing

\section{Introduction}

English is a universal language in today's scientific world, and it plays a significant role in the world's best academic publications. With "Double-First Class" initiative which aims to establish world first class universities and disciplines in China and strive for making China an international higher education power, there is an urgent need for Chinese EFL learners to improve their academic English competence in academic exchanges. For graduate students, they are expected to keep up with the cutting edge of the latest development in their discipline from international journals. A number of them are required to participate in research work including some international projects, to attend international academic conferences, and to make oral presentations and publish journal articles in English. This is a big challenge for EFL learners. Actually, for EFL learners, their English writing activities are greatly restricted by in-class experience. Out of the classroom, they seldom have the environment to use the target language to communicate. Under this condition, the function of foreign language writing is no more than activities of practicing grammar and vocabulary (Sasaki \& Hirose, 1996). Thus, foreign language learners are more likely to be concerned with grammatical aspects than pragmatic aspects in writing (Alco'n, 2005; Bardovi-Harlig \& Dörnyei, 1998; Koike \& Pearson, 2005; Takahashi, 2001, 2005). In other words, writing is regarded as a grammatical tool but not a primary medium to satisfy communicative needs, so EFL learners usually have difficulties developing their awareness of the important relationship between text features and the communicative purpose in different contexts. They are largely confined to the micro-structure of writings, such as words and sentences, but fail to pay due attention to the macro-structure of the overall discourse (Rosemary, 2017). Academic English writing is quite different from general English writing in terms of its purpose, potential readers, text structures and language styles. However, the explicit instruction about how to construct academic writing and choose appropriately from language varieties is insufficient and EAP research is just beginning in China. These make many graduates feel lack of support and confidence in writing academic papers in English and their academic writing proficiency is low.

In addressing this issue, in the past decades, considerable scholars discussed the values of genre-based approach in writing instruction (Belcher, 1994, 2004; Byrnes, 2009; Cheng, 2006, 2007, 2008a, 2008b; Flowerdew, 2002; Gentil, 2005; Hyland, 2007; Swales, 1990; Tardy, 2009). From the systemic functional perspective, genre-based pedagogy emphasizes the interconnection between the form of language and its function in social context (Hyland, 2007). That is, language is used for communicating with others for specific social purposes. Genre-based L2 writing instruction provides explicit and supportive instruction to learners to assist them in understanding the features of discourse (Hyland, 2007). It is widely used in the practice of ESP and EAP (Swales 
\& Feak, 1994, 2000) to meet learners' needs. However, further studies and discussions about the potential possibilities of its application in L2 writing instruction are needed (Cheng, 2006; Hyland, 2007).

From the social cognitive perspective, self-efficacy plays a significant role in the choices and actions a person may make. People's behaviors can often be predicted by their beliefs about their capabilities of doing something (Bandura, 1989). Research into self-efficacy has found that there is a positive relationship between one's level of self-efficacy and academic achievement (e.g.,Pajares, 2003; Pajares \& Kranzler, 1995; Pintrich \& De Groot, 1990; Schunk, 1984). Usually, proficient learners feel more confident and demonstrate a higher level of self-efficacy than that of less proficient learners. Bandura (1997) puts forward that one's prior successes and mastery experiences are the most important factors affecting one's level of self-efficacy. Genre-based L2 writing pedagogy is assumed to be a strong factor that influences L2 learners' self-regulation and self-efficacy (Csizér \& Tankó, 2017; Woodrow, 2011; Yasuda, 2011). This suggests a potential connection between psychological factors and the characteristics of genre-based writing instruction. In teaching and learning, "what is meaningful is not an intervention itself, but rather how individuals relate to it" (Larsen-Freeman, 2016, p. 382). This indicates a medium role played by psychological factors in learners' performance. To find out more about the process of the change of learners' performance, it is helpful for us to explore the underlying psychological reasons. However, studies to examine the change of self-efficacy in the process of genre-based writing instruction are few. The present study is targeted at exploring the relationship between EFL learners' self-efficacy and the academic writing instruction from the genre-based perspective with the purpose of gaining deeper insights into the development of EFL learners' academic writing competence.

\section{Literature Review}

\subsection{Genre-based Pedagogy in L2 Writing}

In the field of L2 writing instruction, the product approach and the process approach have always been the major teaching methods. The product approach originates from behaviourism in which learners are viewed as passive reactors in writing instruction and they need to react accurately to the teacher's stimulus (Nunan, 2000). The product approach emphasizes learners' abilities to produce standard language accurately through imitation of input provided by the teacher but it does not direct writers' attention to the importance of the originality of ideas (Raimes, 1983). That means writing is regarded as a habit formation in which learners learn to master the linguistic knowledge to produce grammatically accurate sentences by following a certain structure. While different from the product approach, the process approach, based on communicative theory and cognitive psychology, puts emphasis on the significance of students' active role in the construction of ideas in the writing process, and the writing instruction should be conducted in a student-centered way. However, the input of basic writing skills and the importance of language knowledge are not given due attention in the writing instruction.

Stemming from the genre theory, the genre-based approach came into the field of L2 writing in the 1980s. Genre is "a set of communicative events. The members of which share some set of communicative purposes" in the social and cultural context (Swales, 1990, p. 58). This definition highlights the basic idea that genres show the use of conventions or rules related to communicative purposes and certain discourse communities, which indicates the focus of the genre-based approach is on achieving communicative purposes in different contexts. There are currently three major schools of genre analysis in the area of L2 writing instruction: the ESP school, Systemic Functional Linguistics school and the New Rhetoric school. Although the three perspectives of genre analysis may differ from each other, there are a lot of overlaps among therm. Writing is viewed as a social and communicative action, and situation and purpose are the key elements a writer should take into consideration. The development of writers' writing abilities largely depends on writers' awareness of required formats, styles and conventions in a given genre. Badger and White (2000) put forward that "the analysis and imitation of input in the form of texts provided by the teacher" (p. 156) plays a significant role in the improvement of writing. The genre-based approach emphasizes the imparting of genre knowledge to learners on the textual level, however, learners are made passively and insufficient attention is paid to learners' needs for basic skills in writing and the requirements for accuracy of their language.

With comparing and analysis of values and limitations of product approach, process approach and genre-based approach, Badger and White (2000) argue that the three approaches are complementary and propose the process-genre approach for writing instruction. The process-genre approach is aimed at enabling learners to have a good command of linguistic knowledge, contextual knowledge and skills in using the language in writing instruction. To be specific, the linguistic knowledge of grammar, words and sentences should not be taught separately from the context, but be taught in meaningful and communicative situations related to genres. By this approach, teachers should guide students to complete writing tasks for a particular communicative purpose at 
five stages. At the very beginning, the teacher constructs a specific social situation and lets students find out the purpose of communication for that situation. Then, the teacher presents a model text of the particular type of genre and discusses how the text is structured and organized to serve for its communicative purpose. On the mastery of communicative purposes of a given genre, the teacher should guide students to analyze the model text from the perspectives of language level and social context level, such as words, sentences, discourses, interlocutors' relationship, and mode of communication. After the former preparations, students are expected to develop their ideas into written text through process writing. Finally, on the feedback for revision, students accomplish their final draft, and students' attention is shifted to the final writing product. It can be concluded that the process-genre approach is a synthesis of the advantages of former teaching methods which puts focus on both the accumulation of language knowledge and writing skills and the role of social context.

Process-genre approach displays the advantages of the process approach and genre-based approach. Teaching writing from the perspective of genre emphasizes language, content and contexts, which provides students with an explicit and systemic way of learning how to write for communicative purposes (Leki, Cumming, \& Silva, 2008). With a clear purpose in mind, students are more likely to carefully plan their writing and monitor their own writing process. Besides, the student-centered writing instruction in process-genre approach promotes the communication between students and the teacher, which is of great benefit for the teacher to provide guided support to meet students' needs in the writing process. While writing, students can get access to both explicit instruction of knowledge and skills related to specific social contexts and other needed guidance from the teacher. All these may contribute to students' positive emotional experiences and improve their confidence and interests in writing.

\subsection{Self-Efficacy and L2 Writing}

From the social-cognitive perspective, self-efficacy is defined as "beliefs in one's capabilities to organize and execute the courses of action required to produce given attainments" (Bandura 1997, p. 3). This means self-efficacy is a personal perception or belief of one's ability to accomplish a task in a particular domain. Learners with a higher level of self-efficacy are more confident in their abilities to organize learning activities in a beneficial way (Bandura, 1986). Since self-efficacy is domain-specific, writing self-efficacy means writers' subjective judgement or evaluation of their capabilities to accomplish a given writing task. Writers with higher writing self-efficacy tend to possess stronger confidence and are more likely to challenge the difficult writing tasks through making greater efforts needed to resolve the problems (Lavelle, 2006).

There are four major sources affecting one's development of self-efficacy (Bandura, 1997): mastery experience, vicarious experience, social persuasion and physiological states. Mastery experience refers to the gained experience from performing tasks. One's previous experiences play a significant role in one's mastery experience. For example, one's experience of fulfilling a writing task successfully functions as a positive role to contribute to the individual's high level of self-efficacy in writing. Vicarious experience is formed from the observation of others, such as friends, classmates or other peers. The successes or achievements made by similar others will help the learner develop a positive belief toward his own abilities, which helps improve his level of self-efficacy. Another factor affecting one's self-efficacy is from social persuasion which means encouragement, praise and other positive comments or feedback that function as a facilitator to enhance one's self-efficacy. In addition, one's physiological and affective states may also play a role in one's personal beliefs and evaluation of his capabilities. Lassitude, anxiety and pressure may all affect one's interpretations and judgement of his abilities in performing a task. For example, learners may take a negative attitude towards a writing task or even give it up because they feel very anxious about it, and this anxiety may be interpreted by themselves as an indicator of their incapability to accomplish the writing task, which results in their low level of self-efficacy. It is claimed that self-efficacy can better predicate one's performance than his actual ability (Bandura, 1989).

Self-efficacy, a key social cognitive factor, takes an active part in people's thinking patterns and behaviors. In academic settings, self-efficacy plays a crucial role in learners' cognition, motivation and actions (Usher \& Pajares, 2008). Self-efficacy influences a person's choices and actions (Bandura, 1993). Learners tend to choose the learning tasks which are within their capabilities. For example, learners with a high level of self-efficacy prefer to perform on more challenging tasks and spend more time and make greater efforts, which, in turn, give them more confidence in learning. Prolific studies have indicated the positive correlation between self-efficacy and L2 performance and achievements (Hsieh \& Kang, 2010). For example, Woodrow (2011) examined the relationship between Chinese EFL learners' writing performance and self-efficacy and found that there was a significant correlation between participants' self-efficacy level and their L2 writing performance. Previous studies also explored the relationship between self-efficacy and strategy use. Yang (1999) reported a significantly positive relationship between Chinese EFL learners' beliefs and their use of functional practice strategies. Wong 
(2005) examined Malaysian ESL undergraduates, and the results showed that students with a higher level of perceived self-efficacy used language learning strategies more frequently than those with a lower level of self-efficacy. Self-efficacy also exerts influence on one's motivation and self-regulation in L2 setting (Woodrow, 2006; Mills et al., 2007). Additionally, self-efficacy plays a role in learners' affective factors. It is found that self-efficacy affects learners' attribution. For example, learners with a high level of self-efficacy tend to attribute their language performance to internal factors under control, such as efforts, while learners who believe that effort does not contribute to their learning performance which is out of control and depends on external factors usually demonstrate a low level of self-efficacy ( Hsieh \& Kang, 2010; Hsieh \& Schallert, 2008; Graham, 2006). Researchers also report that there is a negative link between learners' self-efficacy and their learning anxiety. High efficacious writers feel more confident and tend to have less anxiety about their writing tasks (Cheng, 2002; Woodrow, 2011). Besides, research findings also show that self-efficacy may affect learner's interest, persistence, efforts and goal-setting in performing a task (Lane, Lane, \& Kyprianou, 2004; Linnenbrink \& Pintrich, 2003; Pajares, 2003; Schunk, 2003).

Summarizing previous research, it can be found that self-efficacy plays a significant role in L2 learning, however, studies exploring the change of EFL learners' self-efficacy in academic writing context and factors affecting learners' self-efficacy, especially in process-genre writing instruction are few.

\section{Method}

\subsection{Participants}

The participants in this study were from the first-year graduate students of a Chinese university. Their majors are related to science and engineering (e.g., computer science and information engineering, mechanical engineering, power engineering, etc.). A total of 59 students ( 36 male and 23 female) from a convenient sample participated in the experiment. All the participants were similar in age and their English learning experiences. According to the analysis of their English performance on English test in the postgraduate entrance examination, their English proficiency levels were not significantly different. They were at their first semester of academic English writing course in the master degree program. The course was conducted under the circumstance that a growing number of graduate students were required to be able to read academic papers published in international journals and write their papers in English. However, before this experiment, all of the participants neither had experience nor received any instruction about academic English. After the experiment, five participants were selected randomly to participate in the following interview.

\subsection{Instruments}

Both quantitative and qualitative research methods were employed in the current study, including a questionnaire of self-efficacy and an interview.

A self-efficacy questionnaire for academic English writing was used to explore the general level of participants' self-efficacy and the change of self-efficacy in writing instruction based on process-genre approach. The questionnaire of self-efficacy was designed on the basis of self-efficacy scales constructed in previous studies (Shell, Murphy, \& Brunning, 1989; Tang \& Xu, 2011), which was appropriate to investigate participants' self-efficacy about academic writing. All together there were 20 items concerning participants' academic writing self-efficacy included in the questionnaire and the five-points Likert type scale ranging from 1 to 5 points (strongly disagree to strongly agree) was adopted. The higher the total score was, the higher level of academic writing self-efficacy the participants possessed. To ensure the validity of this instrument, further analysis was conducted to find out that the internal consistency coefficients of the items in questionnaire was 0.91, indicating that the contents of the questionnaire was reliable. All the data collected from the questionnaire were further analyzed through SPSS 16.0.

To supplement the quantitative data, a semi-structured interview was carried out. The questions in the interview were designed to find out more about participants' changes of attitudes and beliefs about their academic writing capabilities and process-genre writing instruction, and the reasons why the changes were made were also examined. Five participants who were willing to participate in the following interview were randomly selected and interviewed. The following questions were used as a guideline to elicit the interviewees' answers towards their writing self-efficacy and process-genre approach in academic writing instruction: 1) How do you feel about your English writing before this course? Why? 2) How do you think of your abilities in academic writing? Why? 3) How do you think of the writing instruction in this lecture? Is it different from your former experience? The interview was conducted in participants' L1 (Chinese) and videotaped for further analysis. Each interview was conducted for 20 minutes. After the interview, all the data gathered from the interview were transcribed by the researcher of the present study. 


\subsection{Procedures}

\subsubsection{Teaching Procedures}

The process-genre approach adopted in the present study was based on the framework proposed by Feez (1998). The teaching and learning process proceeded through the following major steps. First, the teacher helped students establish the context through presenting and analysis of the model of research paper. Before the lecture, students were assigned reading tasks of a certain topic, for example, the introduction part of the assigned research papers. During the class, the teacher first focused on one model paper and guided students to discuss the macro-structure and micro-structure of the model paper. Through discussions, students got explicit information about the purpose, the situational context as well as the conventions of language in the genre of research paper. Then, the teacher guided students to direct their attention to key moves included in each part. The sentences were marked and classified according to the function and communicative purpose. At this stage, both the linguistic features and the genre structures were explicitly discussed. On the basis of the above steps, it came to the stage of initial writing. Students were encouraged to write their first draft by employing the genre knowledge gained from former steps. After students completing their first writing, it was the reviews for students' first draft from two aspects, forms of language and discourse structures. Both peer review and teacher's evaluation were conducted. Finally, it was the stage of revising and final writing. Through the feedback from peers and the teacher, students got a clear evaluation rubrics of research paper which could be used as a guidance for refining their language and improving the content.

\subsubsection{Experiment Procedures}

The questionnaires about participants' self-efficacy were distributed and completed twice. The first time questionnaire was conducted before the experimental teaching process in order to explore participants' initial level of self-efficacy about academic writing. After 14 weeks' experiment, the questionnaire was conducted the second time in the last lecture of the teaching and learning experiment to find out participants' change of self-efficacy. The same set of questions were included in the two questionnaires with a scrambled order. After collecting the questionnaires, five students were chosen randomly to participate the interview to gather more date about participants' attitudes and beliefs about writing academic papers in English and process-genre approach employed in the writing instruction.

\section{Results}

\subsection{Results of Quantitative Data}

To explore participants' overall level of self-efficacy about academic paper writing before the experiment, pre-experiment self-efficacy questionnaire was analyzed. The descriptive data of participants' level of self-efficacy is shown in Table 1.

It was found that the mean score of the participants' self-efficacy was 61.19 and the standard deviation was 3.47. This shows that on average all the participants' confidence in their capabilities of writing academic papers in English is relatively low.

To explore whether participants' self-efficacy has changed through the process-genre writing instruction, the post-questionnaire was carried out after 14 weeks' academic English writing course. The descriptive data of the post-questionnaire is shown in Table 1.

After the experiment, the mean score of participants' self-efficacy was 65.84 and the standard deviation was 1.24. It suggests that participants has improved their confidence in their abilities of academic paper writing compared with that before the experiment, and this difference among participants was decreasing. To find out whether the difference in the level of self-efficacy between post-questionnaire and pre-questionnaire is statistically significant, t-test analysis was employed. As shown in Table 1, the mean score of participants' self-efficacy in post-questionnaire was significantly higher than that in the pre-questionnaire $(t=-2.37, p=0.012<0.05)$, indicating that participants improved their self-efficacy with the process-genre writing instruction.

Table 1. T-test between pre- and post-questionnaire of participants' self-efficacy

\begin{tabular}{llllll}
\hline & N & Mean & SD & T & Sig. (2-tailed ) \\
\hline Pre-questionnaire & 59 & 61.69 & 3.47 & & \\
Post-questionnaire & 59 & 65.84 & 1.24 & $-2.37^{*}$ & 0.012 \\
\hline
\end{tabular}

$* \mathrm{p}<.05$. 


\subsection{Results of Qualitative Data}

After the post-questionnaire, five graduate students, selected randomly from the 59 participants, participated in the following semi-structured interview. Results from the analysis of the interview seem to corroborate with the quantitative data. For the first question, it was found that many factors contributed to EFL learners' lack of confidence in English writing. For all the five students, English writing was viewed as a difficult task for them. They attributed their lack of confidence in English writing to their poor language proficiency levels, such as vocabulary, sentences structures and grammar. In addition, generating ideas and organizing ideas in a logical way also made them hold negative perceptions about their writing abilities.

My writing is poor. Usually I don't have enough vocabulary to convey my ideas, and grammar, yes grammar, I am not sure about whether the grammar used in my writing is accurate or not (Student A).

English writing is difficult for me. It takes a lot of time but I can't make any obvious progress in it.(student B)

Writing is frustrating not only because of the words and sentences but also the relevant ideas to support my points. I just can't come up with ideas. Yes, I don't have too much to say (Student C).

I feel nervous about writing tasks and I find writing is really a challenging task for me. Sometimes I feel at lost about how to arrange all the ideas in a clear way. Everything is messed up (Student D).

However, for the second question, they began to feel more confident and took more positive attitudes toward their capabilities of writing research papers after attending the lectures in the experiment. From the interview, it was found that this change of attitudes or perceptions had much to do with the teaching and learning activities in their writing course. One student mentioned that he felt he could organize his research paper better because of the explicit instruction of writing objectives related to each part. Another student talked about the usefulness of the knowledge about the conventional language used in research papers. And another student felt more confident in his abilities of writing the part of abstract in research papers because of his clear understandings of the logic and meanings in it.

Now I can understand research papers much more easily. The teacher told us (the students) that each part had a specific purpose, and I can imitate the structure of the model text to organize my ideas (Student D).

I've learned a lot about the use of formal words and sentence structures in writing academic papers, which is of great help for me (Student B).

I won't feel very worried when asked me to write an abstract in English because I believe I can organize the contents to include all the necessary key information in a logical way which will not let down my supervisor (Student E).

For the third question, when asked to give comments and evaluations about the process-genre approach used in this academic writing course, all the five students gave positive feedback and they agreed with each other that this approach was useful and helpful to guide them to write research papers and they became more confident in their abilities of writing academic papers in English. One student said the approach was helpful to improve his academic writing abilities and enabled him to have a sense of accomplishment. Two students mentioned a different experience of exchanging ideas with others in writing class. Another two students talked about the usefulness of knowledge about structures, purposes and language use in the academic writing genre that they had acquired in the instruction. Besides, one of the students gave positive comments on the teacher in the writing instruction.

Yes, I think it's very useful. For example, now I have a clear idea about how to write an abstract in English and I feel very satisfied with my work, you know, a sense of fulfillment (Student E).

The class is interesting and helpful. It's not the type of writing class in the past. I talk with other students to get clear ideas and suggestions (Student B).

The class is helpful. For example, I know IMRD structure and I know what's the focus in my discussion now. But in the past, I just wrote what I could think of without any specific purpose in mind (Student C).

The class is different, and I've learned a lot about the structures and language forms used in academic papers. That's very important for me as a graduate student. The teacher is nice and always encourages us. I think there are more communications (Student A).

\section{Discussion}

In the current study, results showed that the overall level of self-efficacy of EFL graduate students in academic writing was relatively low. In the interview, many participants reported their perceptions of lack of writing skills 
and linguistic resources. This shows that the participants' insufficient English proficiency levels may make them feel inadequacy in their writing abilities. Besides, academic writing is quite different from general writing used for other social communication purposes. For the beginning level of graduate students, they don't have too many experiences of writing research papers and know little about the requirements for the formal usage of language and structure in academic context. All these factors may affect participants' level of confidence in academic writing, thus result in a low level of self-efficacy.

The study also found that there was a significant improvement of participants' self-efficacy about their academic writing abilities with the experimental teaching and learning activities. Results from the interview also suggested that process-genre approach played a positive role in cultivating EFL learners' confidence and in enhancing their self-efficacy level of completing writing tasks. This finding is in consistent with previous research that genre-based instruction can develop L2 writers' confidence in writing tasks (Jiwon \& Phil, 2018; Yasuda, 2011). One possible explanation for the improvement of participants' self-efficacy is that process-genre writing instruction provides explicit instruction and needed support for students. With clear guidelines of both language use and context, students have a definite goal and they receive enough input and feel ready through repetitive exposure to research writing papers, which may increase their confidence in completing the writing tasks. In the interview, all the participants regarded the process-genre approach as useful and helpful. Another benefit is that the teacher divides the overall academic writing task into several stages with specific focus at each stage, which makes the writing task more manageable and controllable by the students. Students may feel less stressful and are more likely to experience progress and success with the smaller task at each sub-stage. Increased communications in class may also provide opportunities for students to view other peers' success and hold similar expectations of their own success with efforts. And free discussions and positive feedback also foster a relaxed atmosphere and the development of a positive relationship between the teacher and students, which may enable students to reduce their anxiety and take active participation in writing tasks.

\section{Conclusion}

The present study is aimed at exploring the relationship between the level of self-efficacy and process-genre instruction of academic writing. It was found that the adoption of process-genre approach in graduates' academic writing course made EFL learners more confident in their writing capabilities and they took a more positive attitude towards academic writing.

The research findings provide some implications for writing instruction for academic purposes in EFL context. Process-genre writing instruction provides teachers with an effective way of facilitating EFL learners' access to constructing their writing based on meaningful choices for achieving communicative purposes in different social situations. First, teachers should design in-class activities on the basis of genre analysis of research papers. According to different parts included in research papers: abstract, introduction, method, results and discussion, the teacher should give explicit instruction and support to guide students to acquire the genre knowledge. Second, the teacher should pay attention to the development of students' self-efficacy in writing instruction. It's beneficial to help students cultivate their awareness of writing strategies and skills and encourage them to employ these skills actively to set goals, make plans and monitor their writing process to improve their writing efficiency. Additionally, the cooperation and communication between students offer them a relaxed atmosphere as well as opportunities to observe the success made by peers, which may motivate them to gain confidence to exert greater efforts in writing. Furthermore, peer review and teachers' feedback should be integrated to help students better understand their writing abilities. Teachers should present their feedback and comments on students' writing in a more positive way to encourage students to form a sense of belonging and confidence in writing tasks.

The current study has some limitations for considering when interpreting its major findings. One possible limitation is about the participants in the study who are come from a convenient sample and all of them are at their beginning stage of graduate program, so the representativeness of this study may be limited. Another limitation is that this study only focuses on the change of one of participants' psychological factors, but writing is a complex cognitive process and there may be some interconnections between self-efficacy and other affective variables, so further research is needed to explore deeply into the complex relationship between self-efficacy and other affecting variables.

\section{Acknowledgments}

This research was financially supported by "the Fundamental Research Funds for the Central Universities+2015MS68". 


\section{References}

Alco'n, E. (2005). Does instruction work for learning pragmatics in the EFL context? System, 33, 417-435. https://doi.org/10.1016/j.system.2005.06.005

Bardovi-Harlig, K., \& Dörnyei, Z. (1998). Do language learners recognize pragmatic violations? Pragmatics vs. grammatical awareness in instructed L2 learning. TESOL Quarterly, 32, 233-259. https://doi.org/10.2307/3587583

Badger, R., \& White, G. (2000). A process genre approach to teaching writing. ELT Journal, 54(2), 153-160. https://doi.org/10.1093/elt/54.2.153

Bandura, A. (1986). Social foundations of thought and action:A social cognitive theory. Englewood Cliffs, NJ: Prentice-Hall.

Bandura, A. (1989). Regulation of cognitive processes through perceived self-efficacy. Developmental Psychology, 25 (5), 729-735. https://doi.org/10.1037/0012-1649.25.5.729

Bandura, A. (1993). Perceived self-efficacy in cognitive development and functioning. Educational Psychologist, 28, 117-148. https://doi.org/10.1207/s15326985ep2802_3

Bandura, A. (1997). Self-efficacy: The exercise of control. New York: W. H. Freeman and Co.

Belcher, D. (1994). The apprenticeship model to advanced academic literacy: Graduate students and their mentors. English for Specific Purposes, 13, 23-34. https://doi.org/10.1016/0889-4906(94)90022-1

Belcher, D. (2004). Trends in teaching English for Specific Purposes. Annual Review of Applied Linguistics, 24, 165-186. https://doi.org/10.1017/S026719050400008X

Byrnes, H. (2009). Emergent L2 German writing ability in a curricular context: A longitudinal study of grammatical metaphor. Linguistics and Education, 20, 50-66. https://doi.org/10.1016/j.linged.2009.01.005

Csizér, K., \& Tankó, G. (2017). English majors' self-regulatory control strategy use in academic writing and its relation to L2 motivation. Applied Linguistics, 38, 386-404.

Cheng, Y. (2002). Factors associated with foreign language writing anxiety. Foreign Language Annals, 35(6), 647-656. https://doi.org/10.1111/j.1944-9720.2002.tb01903.x

Cheng, A. (2006). Understanding learners and learning in ESP genre-based writing instruction. English for Specific Purposes, 25, 76-89. https://doi.org/10.1016/j.esp.2005.07.002

Cheng, A. (2007). Transferring generic features and recontextualizing genre awareness: Understanding writing performance in the ESP genre-based literacy framework. English for Specific Purposes, 26, 287-307. https://doi.org/10.1016/j.esp.2006.12.002

Cheng, A. (2008a). Analyzing genre exemplars in preparation for writing: The case of an L2 graduate student in the ESP genre-based instructional framework of academic literacy. Applied Linguistics, 29, 50-71. https://doi.org/10.1093/applin/amm021

Cheng, A. (2008b). Individualized engagement with genre in academic literacy tasks. English for Specific Purposes, 27, 387-411. https://doi.org/10.1016/j.esp.2008.05.001

Flowerdew, J. (2002). Genre in the classroom: A linguistic approach. In A. M. Johns (Ed.), Genre in the classroom: Multiple perspectives (pp. 9-102). Mahwah, NJ: Lawrence Erlbaum Associates.

Feez, S. (1998). Text-based syllabus design. Sydney: McQuarie University/AMES.

Graham, S. (2006). A study of students' metacognitive beliefs about foreign language study and their impact on learning. Foreign Language Annals, 39(2), 296-309. https://doi.org/10.1111/j.1944-9720.2006.tb02267.x

Gentil, G. (2005). Commitments to academic biliteracy: Case studies of francophone university writers. Written Communication, 22, 421-471. https://doi.org/10.1177/0741088305280350

Hsieh, P. H., \& Kang, H. S. (2010). Attribution and self-efficacy and their interrelationship in the Korean EFL context. Language Learning, 60(3), 606-627. https://doi.org/10.1111/j.1467-9922.2010.00570.x

Hsieh, P. H., \& Schallert, D. L. (2008). Implications from self-efficacy and attribution theories for an understanding of undergraduates' motivation in a foreign language course. Contemporary Educational Psychology, 33, 513-532. https://doi.org/10.1016/j.cedpsych.2008.01.003

Hyland, K. (2007). Genre pedagogy: Language, literacy, and L2 writing instruction. Journal of Second Language Writing, 16, 148-164. https://doi.org/10.1016/j.jslw.2007.07.005 
Jiwon, H., \& Phil, H. (2018). Genre-based L2 writing instruction and writing-specific psychological factors: The dynamics of change. Journal of Second Language Writing, 40, 44-59. https://doi.org/10.1016/j.jslw.2018.03.001

Koike, D., \& Pearson, L. (2005). The effect of instruction and feedback in the development of pragmatic competence. System, 33, 481-501. https://doi.org/10.1016/j.system.2005.06.008

Linnenbrink, E. A., \& Pintrich, P. R. (2003). The role of self-efficacy beliefs in studentengagement and learning in the classroom. Reading and Writing Quarterly: Overcoming Learning Difficulties, 19(2), 119-137. https://doi.org/10.1080/10573560308223

Lane, J., Lane, A., \& Kyprianou, A. (2004). Self-efficacy, self-esteem and their impact on academic performance. Social Behaviour and Personality, 32, 247-256. https://doi.org/10.2224/sbp.2004.32.3.247

Lavelle, E.(2006). Teachers' self-efficacy for writing. Electronic Journal of Research in Educational Psychology, 8(4-1), 73-84.

Leki, I., Cumming, A., \& Silva, T. (2008). A synthesis of research on second language writing in English. New York: Routledge.

Mills, N., Pajares, F., \& Herron, C. (2007). Self-efficacy of college intermediate French students: relation to $\begin{array}{llll}\text { achievement and motivation. Language Learning, 57(3), 417-442. } & \text {. }\end{array}$ https://doi.org/10.1111/j.1467-9922.2007.00421.x

Pajares, F. (2003). Self-efficacy beliefs, motivation and achievement in writing. Reading and Writing Quarterly, 19(2), 139-158. https://doi.org/10.1080/10573560308222

Pajares, F., \& Kranzler, J. (1995). Self-efficacy beliefs and general mental ability in mathematical problem solving. Contemporary Educational Psychology, 20, 426-443. https://doi.org/10.1006/ceps.1995.1029

Pintrich, P. R., \& De Groot, E. V. (1990). Motivational and self-regulated learning components of classroom academic performance. Journal of Educational Psychology, 82(1), 33-40. https://doi.org/10.1037/0022-0663.82.1.33

Rosemary, W. (2017). Using mind maps to reveal and develop genre knowledge in a graduate writing course. Journal of Second Language Writing, 38, 58-71. https://doi.org/10.1016/j.jslw.2017.09.005

Raimes, A. (1983). Techniques in teaching writing. New York: Oxford University Press.

Sasaki, M., \& Hirose, K. (1996). Explanatory variables for EFL students expository writing. Language Learning, 46, 137-174. https://doi.org/10.1111/j.1467-1770.1996.tb00643.x

Schunk, D. H. (2003). Self-efficacy for reading and writing: Influence of modeling, goal setting and self-evaluation. Reading and Writing Quarterly: Overcoming Learning Difficulties, 19(2), 159-172. https://doi.org/10.1080/10573560308219

Schunk, D. H. (1984). Enhancing self-efficacy and achievement through rewards and goals: Motivational and informational effects. Journal of Educational Research, 78, 29-34. https://doi.org/10.1080/00220671.1984.10885568

Shell, D. F., Murphy, C. C., \& Bruning, R. H. (1989). Self-efficacy and outcome expectancy mechanisms in reading and writing achievement. Educational Psychology, 81, 91-100. https://doi.org/10.1037/0022-0663.81.1.91

Swales, J. M. (1990). Genre analysis: English in academic and research settings. Cambridge: Cambridge University Press.

Swales, J. M., \& Feak, C. B. (1994). Academic writing for graduate students. Ann Arbor, MI: The University of Michigan. https://doi.org/10.3998/mpub.9059

Swales, J. M., \& Feak, C. B. (2000). English in today's research world: A writing guide. Ann Arbor, MI: The University of Michigan.

Tang, F., \& Xue, J. F. (2011). Research on English writing self-efficacy of Chinese college students. Foreign Language World, 6, 22-29.

Tardy, C. (2009). Building genre knowledge. West Lafayette, IN: Parlor Press.

Takahashi, S. (2001). The role of input enhancement in developing interlanguage pragmatic competence. In K. Rose, \& G. Kasper (Eds.), Pragmatics in language teaching (pp. 171-199). Cambridge: Cambridge 
University Press. https://doi.org/10.1017/CBO9781139524797.014

Takahashi, S. (2005). Noticing in task performance and learning outcomes: A qualitative analysis of instructional effects in interlanguage pragmatics. System, 33, 437-461. https://doi.org/10.1016/j.system.2005.06.006

Nunan, D. (2000). Second language teaching and learning. Bejing: Foreign Language Teaching and Research Press.

Usher, E., \& Pajares, F. (2008). Sources of self-efficacy in school: Critical review of the literature and future directions. Review of Educational Research, 78, 751-796. https://doi.org/10.3102/0034654308321456

Woodrow, L. (2011). College English writing affect: Self-efficacy and anxiety. System, 39, 510-522. https://doi.org/10.1016/j.system.2011.10.017

Woodrow, L. J. (2006). A model of adaptive language learning. Modern Language Journal, 90(3), 297-319. https://doi.org/10.1111/j.1540-4781.2006.00424.x

Wong, M. S. L. (2005). Language learning strategies and language self-efficacy investigating the relationship in Malaysia. RELC Journal, 36(3), 245-269. https://doi.org/10.1177/0033688205060050

Yasuda, S. (2011). Genre-based tasks in foreign language writing: Developing writers' genre awareness, linguistic knowledge, and writing competence. Journal of Second Language Writing, 20, 111-33. https://doi.org/10.1016/j.jslw.2011.03.001

Yang, N. D. (1999). The relationship between EFL learners' beliefs and learning strategy use. System, 27(4), 515-535. https://doi.org/10.1016/S0346-251X(99)00048-2

\section{Copyrights}

Copyright for this article is retained by the author(s), with first publication rights granted to the journal.

This is an open-access article distributed under the terms and conditions of the Creative Commons Attribution license (http://creativecommons.org/licenses/by/4.0/). 